\title{
Clinical-epidemiologic profile of the schistosomal myeloradiculopathy in Pernambuco, Brazil
}

\author{
Karina Conceição GM de Araújo ${ }^{1 /+}$, Cristiana da Rosa e Silva ${ }^{1}$, Alexsandra Glória A dos Santos ${ }^{1}$, \\ Constança Simões Barbosa', Teresa CA Ferrari²
}

${ }^{1}$ Laboratório de Esquistossomose, Centro de Pesquisas Aggeu Magalhães-Fiocruz, Av. Moraes Rego s/no, 50670-420 Recife, PE, Brasil

${ }^{2}$ Departamento de Clínica Médica, Faculdade de Medicina, Universidade Federal de Minas Gerais, Belo Horizonte, MG, Brasil

\begin{abstract}
This was a retrospective descriptive study on a series of cases of schistosomal myeloradiculopathy (SMR) and the aim was to investigate the incidence of this disease and its clinical and epidemiological characteristics in cases diagnosed at three healthcare units in Pernambuco, Brazil between 1994-2006. The data were collected by reviewing the medical records from both the neurological and paediatric outpatient clinics and wards of the Hospital Clinics, Hospital of the Restoration and Pernambuco Mother and Child Institute. To gather the data, a spinal cord schistosomiasis evaluation protocol was used. The diagnoses were based on positive epidemiological evidence of schistosomiasis, clinical findings and laboratory tests (stool parasitological examination or rectal biopsies, magnetic resonance imaging findings and cerebrospinal fluid investigations). A total of 139 cases aged between 2-83 years were found. The most important determinants of SMR were male sex $(66.2 \%)$, contact with fresh water (91\%), origin in endemic regions (39.5\%), lower-limb muscle weakness (100\%), sensory level at the lower thoracic medulla (40.3\%), myeloradicular form (76\%) and presence of eggs in the stool parasitological examination (48\%). This sample indicates the need for intervention policies guided by diagnostic standardization, thereby avoiding disease under-notification.
\end{abstract}

Key words: epidemiology - schistosomiasis - schistosomal myeloradiculopathy - neuroschistosomiasis - Schistosoma mansoni

The term neuroschistosomiasis indicates the involvement of the central nervous system by Schistosoma, with or without symptoms. Although any part of the central nervous system may be affected, infection is generally classified into two types, encephalic neuroschistosomiasis and myeloradiculopathy (Ferrari et al. 2008).

Spinal cord schistosomiasis is a severe form of schistosomal infection. In many cases, schistosomal myeloradiculopathy (SMR) is highly suggestive in individuals with epidemiological antecedents of this infection (Ferrari 1999).

Regarding the clinical presentations of schistosomiasis, it is known that in endemic areas, infection with Schistosoma mansoni tends to occur during childhood, with clinical manifestations mainly presenting during adolescence or adulthood. Because the disease may seriously harm the affected individuals, it becomes necessary to understand the clinical-epidemiologic situation of SMR in areas where there is a risk of transmission. All age groups are susceptible to the nervous form, which has been diagnosed in children, adolescents and adults (Paz et al. 2002).

SMR is more frequent than the symptomatic cerebral form, although fewer than 500 cases have been reported since the initial description of the disease in 1930 (Fer-

+ Corresponding author: karina@cpqam.fiocruz.br

Received 22 January 2009

Accepted 13 November 2009 rari et al. 2008). The manifestations result from spinal cord and/or nerve root involvement, most often in the lower thoracic, lumbar, cone and cauda equina regions (Peregrino et al. 1988, Lambertucci et al. 2007). In the medullary form, a picture similar to transverse myelitis is observed; in the myeloradicular form, there is an association of spinal cord and nerve root manifestations. In the cone and cauda equina syndromes, the caudal medulla and nerve roots that form the cauda equine are involved (Silva et al. 2004).

Histories of both exposure to the worm or previous infection aid in the diagnosis. Nonetheless, SMR may occur in the absence of such reports and, moreover, in the absence of any past or present manifestation of the schistosomal infection or many years after the intestinal manifestations have disappeared. Initially, such patients present lumbar or lower-limb pain, followed by bladder dysfunction, weakness and paresthesia of the lower limbs and sexual impotence (Ferrari 1999, Santos et al. 2001, Silva et al. 2004). The progression is acute or subacute, lasting 15 days on average, until the full establishment of myeloradiculopathy. Spontaneous clinical improvement is sometimes described, although recurrence is frequent (Lechtenberg \& Vaida 1977, Marra 1993). In the absence of treatment, $95 \%$ of patients are left with neurological sequelae such as motor dysfunction of the lower limbs and sphincter and erectile dysfunctions, or their condition may cause death (Peregrino et al. 1988, Haribhai et al. 1991, Ferrari 1999, Silva et al. 2004).

The diagnosis of SMR is essentially presumptive and based on clinical and epidemiological data. The difficulty in carrying out complementary examinations in our setting in order to rule out other causes of transverse 
myelitis gives rise to further difficulty in diagnosing this disorder (Spina-França et al. 1980, Scrimgeour \& Gajdusek 1985, Peregrino et al. 1988, Lambertucci et al. 2007). According to Ferrari (1997), considering that the clinical picture of SMR is nonspecific, the presumptive diagnosis could be erroneous, particularly in highly endemic areas because schistosomal infection may only be coincident with a myelopathy of another aetiology.

The objective of the present study was to investigate the incidence of this disease and its clinical and epidemiological characteristics in the patients who were seen at three healthcare units in Pernambuco (PE), Brazil between 1994-2006.

\section{PATIENTS, MATERIALS AND METHODS}

A retrospective descriptive study was conducted on a series of cases of SMR by reviewing the medical records from the neurological and paediatric outpatient clinics and wards of the Hospital Clinics (HC), Hospital of the Restoration (HR) and Pernambuco Mother and Child Institute (IMIP) in Recife, PE, covering 13 years (19942006). The reference time period for this study (13 years) was defined according to the specific nature of case-series studies, which make it possible to standardize information acquired over a period of time, thereby diluting the effects of changes in health professionals and differences in nursing standards and treatment regimens.

All SMR cases of adult and child patients admitted to these three institutions over the defined study period were included. All of these patients came from the metropolitan region of Recife or from other "mesoregions" of PE (Zona da Mata, agreste, sertão or São Francisco). Cases of recurrence and those referred or transferred from other units were taken into consideration, but individuals with undefined diagnoses, associated neurological diseases or myelopathy of other aetiologies were excluded from the study. Cases for which data were not available in the medical records (in spite of having fulfilled the diagnostic criteria established for this study) were also excluded. These criteria were followed with the aim of including as many cases as possible, taking into account possible, probable and proven cases of SMR as defined in the specialized literature (Ferrari 1997, Santos et al. 2001, Valença 2002).

The data were gathered according to a spinal cord schistosomiasis evaluation protocol that was adapted from and based on the criteria of Ferrari (1997). Because of the nature of the data, descriptive statistics were used for the analysis. Measurements of central trend (mean) and variability (standard deviation) were used for describing age. The other data were distributed as absolute and relative frequencies and were analysed as simple percentages and, when possible, by the Chi-square comparative test.

\section{RESULTS}

In the three hospitals, we found a total of 139 cases of SMR. Table I presents the case distribution according to the age group and sex. The largest number of cases was in the age group from 20-40 years (considering both sexes), representing $39.6 \%$ of the entire sample. This group was followed by the age group younger than 20 years
(37.4\%). The youngest patient was two years old and the oldest was 83 years old, with a mean of 22.9 years and standard deviation of 16.6 years. No statistically significant difference was observed regarding the sex and age distributions of the SMR cases.

Among the 139 patients with SMR, 55 (39.5\%) came from an endemic area (Zona da Mata) and 84 (60.5\%) from localities that are considered non-endemic for schistosomiasis. The non-endemic areas corresponded to the following "mesoregions" of PE: metropolitan, agreste and sertão. Information regarding contact with some type of fresh water (river, lagoon, lake, pond, dam, irrigation ditch, stream, reservoir or others) was available in 111 cases. From that information, 101 individuals $(91 \%)$ reported past contact with fresh water.

With regard to the signs and symptoms observed in the SMR cases (Table II), muscle weakness in the lower limbs, gait disorder, lumbar and/or lower-limb pain, touchpainful hypoesthesia or anaesthesia and bladder dysfunction were the most frequent clinical manifestations.

\section{TABLE I}

Distribution of schistosomal myeloradiculopathy cases according to sex and age group at three hospitals in Recife, Pernambuco, Brazil (1994-2006)

\begin{tabular}{lcccccc}
\hline \multirow{2}{*}{$\begin{array}{l}\text { Age group } \\
\text { (years) }\end{array}$} & \multicolumn{2}{c}{ Males } & \multicolumn{2}{c}{ Females } & \multicolumn{2}{c}{ Total } \\
\cline { 2 - 7 }$<20$ & 30 & 32.6 & 22 & 46.8 & 52 & 37.4 \\
$20-40$ & 39 & 42.4 & 16 & 34 & 55 & 39.6 \\
$40-60$ & 20 & 21.7 & 7 & 15 & 27 & 19.4 \\
$\geq 60$ & 3 & 3.3 & 2 & 4.2 & 5 & 3.6 \\
\hline Total & 92 & 100 & 47 & 100 & 139 & 100 \\
\hline
\end{tabular}

$\mathrm{p}=0.050$.

\section{TABLE II}

Distribution of the neurological signs and symptoms observed in the schistosomal myeloradiculopathy cases at three hospitals in Recife, Pernambuco, Brazil (1994-2006)

\begin{tabular}{|c|c|c|c|c|c|}
\hline \multirow[b]{2}{*}{ Signs and symptoms } & \multicolumn{2}{|c|}{ Present } & \multicolumn{2}{|c|}{ Absent } & \multirow[b]{2}{*}{ Total } \\
\hline & $\mathrm{n}$ & $\%$ & $\mathrm{n}$ & $\%$ & \\
\hline Lumbar and/or lower-limb pain & 106 & 80.3 & 26 & 19.7 & 132 \\
\hline Lower-limb paresthesia & 70 & 57.4 & 52 & 42.6 & 122 \\
\hline $\begin{array}{l}\text { Touch-painful hypoesthesia } \\
\text { or anaesthesia }\end{array}$ & 111 & 89.5 & 13 & 10.5 & 124 \\
\hline Bladder dysfunction $^{a}$ & 106 & 78.5 & 29 & 21.5 & 135 \\
\hline Intestinal dysfunction ${ }^{a}$ & 83 & 60.6 & 54 & 39.4 & 137 \\
\hline Lower-limb muscle weakness & 134 & 100 & 0 & 0 & 134 \\
\hline Gait disorder & 119 & 93.7 & 8 & 6.3 & 127 \\
\hline
\end{tabular}

$a$ : in 52 cases (38.5\%) double dysfunction (bladder and intestine) was observed. 
In relation to the abnormalities of the deep tendon reflexes, it was observed that either the Achilles or patellar reflexes were absent or hypoactive in 79 cases (56.8\%). The Babinski sign was present in $27.3 \%$ of the cases; however, the indifferent response to the plantar reflex predominated $(38.9 \%)$ (Table III).

Table IV details the level of the lesion identified in the SMR patients according to the sensory level observed in the neurological examination by the patient's physician. It was observed that the low thoracic segment of the spinal cord was the most frequently affected region, followed by the lumbar segment. The cervical spinal cord was involved in two cases $(1.4 \%)$. No data on lesion level were available in 38 of the medical records (27.4\%).

It was possible to recognise the clinical form of the disease in 129 cases. Among those, the myeloradicular form presented the highest percentage (76\%), followed by the medullary form $(15.5 \%)$ and the cone and cauda equina syndrome $(8.5 \%)$.

Table V shows the results of the complementary tests. Stool parasitological examinations were performed in 94 cases and revealed S. mansoni eggs in 45 of them (48\%). In 45 out of the 139 SMR cases, the result from this examination was not available in the medical records, or the test was not performed. Rectal biopsies were only performed in nine cases, of which four were children seen at HR and five were patients assisted at HC. Five of these biopsies (55.5\%) showed granulomas.

Regarding the investigation of antibodies against Schistosoma antigens in the cerebrospinal fluid, the most frequent technique used at the $\mathrm{HR}$ and $\mathrm{HC}$ was the immunoenzymatic assay (ELISA). Among the 58 cases from

\section{TABLE III}

Distribution of the deep tendon reflex responses observed in the schistosomal myeloradiculopathy cases at three hospitals in Recife, Pernambuco, Brazil (1994-2006)

\begin{tabular}{lcc}
\hline Reflex response & $\mathrm{n}$ & $\%$ \\
\hline Achilles & & \\
$\quad$ Normal & 24 & 17.3 \\
Absent or diminished & 79 & 56.8 \\
Increased & 24 & 17.3 \\
Not available & 12 & 8.6 \\
Total & 139 & 100 \\
Patellar & & \\
Normal & 22 & 15.9 \\
Absent or diminished & 79 & 56.8 \\
Increased & 32 & 23 \\
Not available & 6 & 4.3 \\
Total & 139 & 100 \\
Plantar & & \\
Flexion (Babinski sign) & 38 & 27.3 \\
Extension & 26 & 18.7 \\
Indifferent & 54 & 38.9 \\
Not available & 21 & 15.1 \\
Total & 139 & 100 \\
\hline
\end{tabular}

the HR in which cerebrospinal fluid did not show a positive reaction to the ELISA test, anti-Schistosoma antibodies were identified in the serum of six cases (10.3\%). Antibody investigation using indirect immunofluorescence was positive in $70 \%$ of the cases evaluated. This was the test most frequently used in the routine at IMIP.

\section{TABLE IV}

Distribution of schistosomal myeloradiculopathy cases according to the level of the lesion at three hospitals in Recife, Pernambuco, Brazil (1994-2006)

\begin{tabular}{lcc}
\hline Level of the lesion & $\mathrm{n}$ & $\%$ \\
\hline Cervical & 2 & 1.4 \\
Low thoracic & 56 & 40.3 \\
Thoracic-lumbar & 13 & 9.4 \\
Lumbar & 22 & 15.8 \\
Lumbar-sacral & 1 & 0.7 \\
Sacral & 5 & 3.6 \\
Cone and cauda equine & 2 & 1.4 \\
Unavailable data & 38 & 27.4 \\
\hline Total & 139 & 100 \\
\hline
\end{tabular}

\section{TABLE V}

Distribution of schistosomal myeloradiculopathy cases according to complementary examinations at three hospitals in Recife, Pernambuco, Brazil (1994-2006)

\begin{tabular}{|c|c|c|c|c|c|}
\hline Examinations & HR & $\mathrm{HC}$ & IMIP & Total & $\%$ \\
\hline \multicolumn{6}{|l|}{ Stool parasitological examination } \\
\hline Presence of schistosomal eggs & 22 & 19 & 4 & 45 & 48 \\
\hline Absence of schistosomal eggs & 40 & 7 & 2 & 49 & 52 \\
\hline Total & 62 & 26 & 6 & 94 & 100 \\
\hline \multicolumn{6}{|l|}{$\begin{array}{l}\text { Cerebrospinal fluid } \\
\text { (indirect immunofluorescence) }\end{array}$} \\
\hline Positive & - & 17 & 4 & 21 & 70 \\
\hline Negative & - & 5 & 4 & 9 & 30 \\
\hline Total & - & 22 & 8 & 30 & 100 \\
\hline \multicolumn{6}{|l|}{ Cerebrospinal fluid (ELISA) } \\
\hline Positive & 37 & 22 & 2 & 61 & 49.2 \\
\hline Negative & 58 & 4 & 1 & 63 & 50.8 \\
\hline Total & 95 & 26 & 3 & 124 & 100 \\
\hline \multicolumn{6}{|l|}{ Magnetic resonance imaging } \\
\hline Abnormal & 62 & 11 & 6 & 79 & 93 \\
\hline Normal & 3 & 2 & 1 & 6 & 7 \\
\hline Total & 65 & 13 & 7 & 85 & 100 \\
\hline \multicolumn{6}{|l|}{ Rectal biopsy } \\
\hline Presence of granulomas & 2 & 3 & - & 5 & 55.5 \\
\hline No abnormalities & 2 & 2 & - & 4 & 45.5 \\
\hline Total & 4 & 5 & - & 9 & 100 \\
\hline
\end{tabular}

HC: Hospital Clinics; HR: Hospital of the Restoration; IMIP: Pernambuco Mother and Child Institute. 
The results of spinal cord examination using magnetic resonance imaging showed abnormalities in the vast majority of the cases $(93 \%)$, with altered signal intensity extending from the cervical region (in a few cases) to the thoracic and lumbar regions and to the cone and cauda equine. Data on imaging methods were available in 54 cases.

\section{DISCUSSION}

Brazil is one of the most important endemic areas for schistosomiasis mansoni and PE is one of the states with greatest prevalence of this infection in the Northeastern Region. Moreover, systematic studies on central nervous system involvement in schistosomiasis are very scarce. Therefore, it is important to investigate and publish data on the neurological manifestations of this disease, with the aim of achieving better comprehension of SMR from the epidemiological, clinical and pathogenetic points of view.

Literature data demonstrate that there is a clear predominance of schistosomiasis in men compared to women (Peregrino et al. 1988, 2002, Brito et al. 1992, Nobre et al. 2001, Santos et al. 2001). In the present study, among the patients with SMR, $66.2 \%$ were male. The predominance of the infection in the male sex may be explained by the fact that men are more frequently exposed to schistosomes, for example in rivers and lakes, because of their professional and/or leisure activities which also require greater physical strength (Nobre et al. 2001, Santos et al. 2001).

With regard to age, the investigations have revealed that this disease continues to be more frequent in young adults (Ferrari 1999, Moreno-Carvalho et al. 2003). Nobre et al. (2001) and Santos et al. (2001) found higher frequencies of SMR cases among adults at mean ages of 24 and 28 years, respectively. Silva et al. (2004) reported a mean of 26 years of age and a range from 1-68 years. Lima (1998) showed that SMR occurred predominantly in adults, with a mean age of around 30 years and a range from 14-73 years. In agreement with the literature, the present paper showed that the cases occurred predominantly in the age group from $20-40$ years $(39.6 \%)$, independently of the sex. Socioeconomic factors probably contribute to the greater predominance in this age group because young adults are the most productive age group and therefore more frequently exposed to the infection (Matas 2001, Santos et al. 2001).

In the present study, 34 out of the 52 SMR individuals younger than 20 years of age were children aged between 0-14 years. It should be noted that the $\mathrm{HC}$ and HR serve both adults and children, whereas IMIP only serves children. This may have contributed to the relatively high proportion of children in the present study. This high number of children reinforces the statement by Rosemberg and Arita (1991) that this disease is underdiagnosed in children; thus, some cases go unnoticed. This occurs because SMR is infrequently remembered when making the differential diagnosis of acute inflammatory myelopathy in children. In many regions, schistosomiasis affects a considerable percentage of children under the age of 14 years, thereby causing dramatic consequences regarding their physical and intellectual development (Farinazzo et al. 1997). Although reports on cases of SMR in children are infrequent, they comprise significant proportions of the cases in some studies (Moreira 1998, Peregrino et al. 2002, Araújo et al. 2006, Santos 2006).

Emphasizing the epidemiological history of schistosomiasis, it was observed in the present study that $91 \%$ of the patients had contact with some type of fresh water (rivers, lakes, lagoons or marshes, among others). In 28 cases, no information about this issue was described in the medical records. According to Costa et al. (1992), the epidemiological history is variable and may involve not only individuals who habitually make contact with rivers, but also those who have sporadic contact. The occasional nature of such contacts does not rule out the possibility of acquiring the infection.

Considering the Americas, Brazil is the country where SMR occurs most frequently. The transmission of this infection occurs most intensely in forested areas of some northeastern states (Silva 1992). In the present study, $39.5 \%$ of the patients came from regions that are considered highly endemic for schistosomiasis, while $60.5 \%$ came from areas with isolated foci of the disease. This result deserves to be highlighted because, in fact, it shows a change in the epidemiological profile of the disease in PE, as mentioned by Barbosa et al. (1996). Other studies have shown that the prevalence of schistosomiasis is still high in both rural (Favre et al. 2001) and coastal areas in PE (Barbosa et al. 2001).

The signs and symptoms observed in this study are in agreement with the findings reported in the literature. In a review conducted by Silva et al. (2004), the most frequent initial clinical manifestation was lumbar and/or lower-limb pain, followed by bladder dysfunction, lower-limb weakness, paresthesia and sexual impotence. In a study by Moreira (1998), which included 12 cases, the following findings were described: paresthesia in $25 \%$ of the patients, urinary dysfunction in $100 \%$, constipation in $50 \%$ and lumbar pain in $54.5 \%$. The prevalence of hypo-anaesthesia as a manifestation of SMR has been reported in several studies (Haribhai et al. 1991, Ferrari 1997, Ferrari et al. 2004).

Regarding the deep tendon reflexes, the most frequently altered ones were the patellar and Achilles reflexes. Areflexia predominates, followed by hyporeflexia, normoreflexia and hyperreflexia (Rosemberg \& Arita 1991, Lima 1998, Paz et al. 2002). We also observed the predominance of areflexia (56.8\%) in both Achilles and patellar reflexes. Regarding the plantar reflex, flexion was observed in $27.3 \%$ of the cases and indifferent response (no reflex) in $38.9 \%$. This last finding is in agreement with the results from Costa et al. (1992) and Tedrus et al. (1996), who observed that the plantar reflex was predominantly indifferent.

The findings related to the classification according to clinical form were similar to what was observed by other authors (Rosemberg \& Arita 1991, Lima 1998, Santos et al. 2001, Paz et al. 2002, Peregrino et al. 2002, Ferrari et al. 2004, Lambertucci et al. 2005). For example, the predominant clinical form of the disease was the my- 
eloradicular one (76\%), which agrees with the findings of Santos et al. (2001) and Moreira (1998), who identified this clinical form in $31(55.3 \%)$ out of the 56 patients and in six (50\%) out of the 12 cases, respectively. In the study by Peregrino et al. (2002), the myeloradicular form also predominated, accounting for $14(77.7 \%)$ out of the 18 patients who underwent magnetic resonance imaging and 19 (79.1\%) out of the 24 patients who underwent electroneuromyography.

The lower thoracic and lumbar-sacral portions of the spinal cord have been reported as the most frequently affected ones. Occasionally, higher levels like T2-T3 may also be involved (Brito et al. 1992, Nobre et al. 2001, Santos et al. 2001, Paz et al. 2002). Like the observations made by the other authors, the present study found that the lower thoracic region of the spinal cord accounted for the largest proportion of cases (40.3\%), followed by the lumbar region (15.8\%).

In order to confirm the diagnosis of SMR, histopathological examination of the spinal cord obtained by biopsy would be necessary. However, this procedure carries a high risk of complications because it is invasive and may injure the nerve tissue even more. Therefore, it should be reserved for doubtful cases or those that do not respond to treatment (Peregrino et al. 1988, 2002, Lambertucci et al. 2005, 2007). In this context, it is important to comment on the necessity of identifying other laboratory evidence that, in association with the clinical and epidemiological findings, could corroborate the diagnosis of SMR.

The distribution of the samples investigated according to laboratory test results showed that schistosomal eggs were observed on the stool parasitological examination in $48 \%$ of the cases. However, it should be emphasized that, in the remaining patients (52\%), only a single sample of faeces was examined. This fact is probably responsible for false negative results, given that a single faeces sample examination is insufficient to rule out the presence of the helminth eggs. Moreover, as reported by Asano (1992), the poor distribution of eggs in the faecal bolus, the daily variation in oviposition and the relatively common existence of low egg concentrations in infected individuals are factors that may lead to diagnostic failure in the parasitological faeces examination, particularly when this examination is limited to a single sample.

Serological analysis of cerebrospinal fluid has become indispensable in cases of spinal cord diseases, as stated by Tedrus et al. (1996). In the present study, a smaller proportion of samples $(49.2 \%)$ were reactive in ELISA compared to the indirect immunofluorescence technique (70\%). It should be emphasized that the latter technique was not a routine procedure at the HR. In this hospital, serum and/or cerebrospinal fluid from 95 out of the 100 patients with SMR were investigated for the presence of antibodies against Schistosoma antigens using the ELISA technique, from whom only 37 presented reactive results. Other studies have shown the promising potential of serological tests on cerebrospinal fluid for diagnosing this entity (Pammenter et al. 1991, Ferrari et al. 1995, Ferrari 1997). However, these tests need to be validated and standardized.
Magnetic resonance imaging showed abnormalities (increased spinal cord diameter at cervical, the thoracic, lumbar and/or medullary cone levels and/or thickening of the cauda equine roots) in $93 \%$ of the 85 patients who underwent this examination. In a study by Paz et al. (2002), five patients who underwent magnetic resonance imaging presented increased diameters of the spinal cord, predominantly at the thoracic-lumbar level, while the result was normal in one case. This is therefore an examination of high sensitivity that is useful in the diagnostic approach of SMR, as stated by Tedrus et al. (1996) and Peregrino et al. (2002).

As observed in relation to magnetic resonance imaging, there were no data on rectal biopsies in the medical records of 130 patients. In a prospective study conducted by Ferrari (1997), parasitological faeces examinations were ordered for all patients, consisting of a series of 3-5 samples and rectal biopsies were ordered for most patients. S. mansoni eggs were found in $58.7 \%$ of the 46 cases whose faeces were examined and in $93.6 \%$ of the 45 cases who underwent rectal biopsy, thus showing that the latter method presented higher sensitivity.

Knowledge about the clinical and epidemiological profile of SMR contributes to better understanding this disease, thus making it easier for health professionals to identify the cases and plan the healthcare actions. Although our data may not be representative of what occurs throughout Brazil, they certainly provide auxiliary information for the scientific community involved in diagnosing, treating and dealing with this disease.

\section{REFERENCES}

Araújo KCGM, Rosa e Silva C, Barbosa CS, Ferrari TCA 2006. Clinical-epidemiological profile of children with schistosomal myeloradiculopathy attended at the Instituto Materno-Infantil de Pernambuco. Mem Inst Oswaldo Cruz 101 (Suppl. I): 149-156.

Asano NMJ 1992. Neuroesquistossomose: aspectos clínicos, laboratoriais e de imunodiagnóstico, MSc Thesis, Universidade Federal de Pernambuco, Recife, 119 pp.

Barbosa CS, da Silva CB, Barbosa FS 1996. Esquistossomose: reprodução e expansão da endemia no estado de Pernambuco no Brasil. Rev Saude Publica 30: 609-616.

Barbosa CS, Domingues AL, Abath F, Montenegro SM, Guida U, Carneiro J, Tabosa B, Moraes CN, Spinelli V 2001. Epidemia de esquistossomose aguda na praia de Porto de Galinhas, Pernambuco, Brasil. Cad Saude Publica 17: 725-728.

Brito JCF, Gonçalves da Silva JA, Silva EB, Viana NO 1992. Neuroesquistossomose medular: avaliação clínico-laboratorial de 5 casos. Arq Neuropsiquiatr 50: 207-211.

Costa RO, Gameleira FT, Tenório RB, Brás LH, Costa VB, Pinto Jr JM 1992. Neuroesquistossomose em Alagoas. Rev Bras Neurol 28: 79-84.

Farinazzo RJM, Batista RS, Lopes F, Ramos Júnior AN, Quintas LEM, Corrêa AD 1997. Bases patológicas da esquistossomose mansoni. Arq Bras Med 71: 107-110.

Favre TC, Pieri OS, Barbosa CS, Beck L 2001. Avaliação das ações de controle da esquistossomose implementadas entre 1977 e 1996 na área endêmica de Pernambuco, Brasil. Rev Soc Bras Med Trop 34: 569-576.

Ferrari TC 1997. Abordagem diagnóstica da mielorradiculopatia causada pelo Schistosoma mansoni: imunodiagnóstico em líquor 
pela técnica de ELISA, PhD Thesis, Universidade Federal de Minas Gerais, Belo Horizonte, 207 pp.

Ferrari TC 1999. Spinal cord schistosomiasis. A report of 2 cases and review enphasizing clinical aspects. Medicine (Baltimore) 78: $176-190$.

Ferrari TC, Drummond S, Reis MG 2008. Neuroesquistossomose. In OS Carvalho, PMZ Coelho, HL Lenzi (orgs.), Schistosoma mansoni e esquistossomose: uma visão multidisciplinar, Editora Fiocruz, Rio de Janeiro, p. 805-820.

Ferrari TC, Moreira PR, Cunha AS 2004. Spinal cord schistosomiasis: a prospective study of 63 cases emphasizing clinical and therapeutic aspects. J Clin Neurosci 11: 246-253.

Ferrari TC, Moreira PR, Oliveira RC, Ferrari ML, Gazzinelli G, Cunha AS 1995. The value of an enzyme-linked immunosorbent assay for the diagnosis of schistosomiasis mansoni myeloradiculopathy. Trans R Soc Trop Med Hyg 89: 496-500.

Haribhai HC, Bhigjee AI, Bill PL, Pammenter MD, Modi G, Hoffmann M, Kelbe C, Becker P 1991. Spinal cord schistosomiasis. A clinical, laboratory and radiological study with a note on therapeutic aspects. Brain 114: 709-726.

Lambertucci JR, Silva LC, do Amaral RS 2007. Guidelines for the diagnosis and treatment of schistosomal myeloradiculopathy. Rev Soc Bras Med Trop 40: 574-581.

Lambertucci JR, Souza-Pereira SR, Silva LC 2005. Myeloradiculopathy in acute schistosomiasis mansoni. Rev Soc Bras Med Trop 38: 277-278.

Lechtenberg R, Vaida GA 1977. Schistosomiasis of the spinal cord. Neurology 27: 55-59.

Lima AC 1998. Neuroesquistossomose: estudo descritivo de 31 casos do Serviço de Neurologia do Hospital da Restauração, Monograph, Recife, 32 pp.

Marra B 1993. Aspects evolutifs d'une myelopathie bilharzienne a Schistosoma mansoni. Med Trop 53: 455-470.

Matas SLA 2001. Neuroesquistossomose. Rev Neurocienc 9: 27-31.

Moreira MASA 1998. Neuroesquistossomose medular na infância estudo de 12 casos, Monograph, Recife, $31 \mathrm{pp.}$

Moreno-Carvalho OA, Nascimento-Carvalho CM, Bacelar AL, Andrade-Filho A de S, Costa G, Fontes JB, Assis T 2003. Clinical and cerebrospinal fluid (CSF) profile and CSF criteria for the diagnosis of spinal cord schistosomiasis. Arq Neuropsiquiatr 61: 353-358.

Nobre V, Silva LC, Ribas JG, Rayes A, Serufo JC, Lana-Peixoto MA,
Marinho RFZ, Lambertucci JR 2001. Schistosomal myeloradiculopathy due to Schistosoma mansoni: report on 23 cases. Mem Inst Oswaldo Cruz 96 (Suppl.): 137-141.

Pammenter MD, Haribhai HC, Epstein SR, Rossouw EJ, Bhigjee AI, Bill PL 1991. The value of immunological approaches to the diagnosis of schistosomal myelopathy. Am J Trop Med Hyg 44: 329-335.

Paz JA, Valente M, Casella EB, Marques-Dias MJ 2002. Spinal cord schistosomiasis in children: analysis of seven cases. Arq Neuropsiquiatr 60: 224-230.

Peregrino AJ, de Oliveira SP, Porto CA, Santos LA, de Menezes EE, Silva AP, Brito AL, Pinheiro SP, Pinheiro S, Dias AB 1988 Meningomielorradiculite por Schistosoma mansoni: protocolo de investigação e registro de 21 casos. Arq Neuropsiquiatr 46: 49-60.

Peregrino AJ, Puglia PM, Nobrega JP, Livramento JA, Marques-Dias MJ, Scaff M 2002. Esquistossomose medular: análise de 80 casos. Arq Neuropsiquiatr 60: 603-608.

Rosemberg S, Arita FN 1991. Mielopatia por esquistossomose mansônica em crianças. Rev Bras Neurol 27: 103-107.

Santos AGA 2006. Perfil clínico e epidemiológico dos portadores de mielorradiculopatia esquistossomótica atendidos no Hospital das Clínicas de Pernambuco, MSc Thesis, Universidade Federal de Pernambuco, Recife, 80 pp.

Santos EC, Campos GB, Diniz AC, Leal JC, Rocha MO 2001. Perfil clínico e critérios diagnósticos da mielorradiculopatia esquistossomótica. Arq Neuropsiquiatr 59: 772-777.

Scrimgeour EM, Gajdusek DC 1985. Involvement of the central nervous system in Schistosoma mansoni and S. haematobium infection. A review. Brain 108: 1023-1038.

Silva LCS, Maciel PE, Ribas JGR, Pereira SRS, Serufo JC, Andrade LM, Antunes CM, Lambertucci JR 2004. Mielorradiculopatia esquistossomótica. Rev Soc Bras Med Trop 39: 261-272.

Silva LJ 1992. A esquistossomose mansônica no estado de São Paulo: origens, distribuição, epidemiologia e controle, Thesis, Universidade Estadual de Campinas, Campinas, 140 pp.

Spina-França A, Salum PNB, Limongi JCP, Berger A, Losso ER 1980. Mielopatias: aspectos diagnósticos. Arq Neuropsiquiatr 38: 360-366.

Tedrus GMA, Viana MA, Fonseca LC, Araújo CR 1996. Neuroesquistossomose. Rev Cien Med 5: 21-23.

Valença MM 2002. Critérios diagnósticos da esquistossomose mansônica meningomielorradicular. Arq Neuropsiquiatr 60: 181-182. 